The Bangladesh Veterinarian (2011) 28(2) : 70 - 74

\title{
Effects of probiotics on serum biochemical parameters in rats
}

\author{
A. Mustari and N. Ahmad \\ Department of Physiology, Faculty of Veterinary Science, Bangladesh Agricultural \\ University, Mymensingh-2202, Bangladesh
}

\begin{abstract}
Twelve one-month-old rats (Rattus norvegicus) were randomly divided into three groups of four. All groups were fed commercial diet, $20 \mathrm{~g} /$ rat for seven days. In addition, groups A and B were given home made probiotic (curd), commercial probiotic (Bio-Top ${ }^{\circledR}$ ). Total serum cholesterol in A, B and C was $91.6 \pm 3.6,92.1 \pm 1.2 \mathrm{mg}, 122.3 \pm 4.9 \mathrm{mg} / \mathrm{dl}$, respectively. Triglyceride in A $(47.5 \pm 16.4 \mathrm{mg} / \mathrm{dl}), \mathrm{B}(44.0 \pm 5.0 \mathrm{mg} / \mathrm{dl})$ and $\mathrm{C}(146.4 \pm 25.4$ $\mathrm{mg} / \mathrm{dl}$ ) differed significantly $(\mathrm{P}<0.01)$. High Density Lipoprotein (HDL) in A $(79.2 \pm 0.4$ $\mathrm{mg} / \mathrm{dl}), \mathrm{B}(80.5 \pm 0.9 \mathrm{mg} / \mathrm{dl}), \mathrm{C}(73.7 \pm 1.3 \mathrm{mg} / \mathrm{dl})$ and Low Density Lipoprotein (LDL) in A $(2.8 \pm 0.2 \mathrm{mg} / \mathrm{dl}), B(2.9 \pm 0.3 \mathrm{mg} / \mathrm{dl}), \mathrm{C}(19.3 \pm 5.9 \mathrm{mg} / \mathrm{dl})$ also differed significantly $(\mathrm{P}<0.01)$. Serum aspartate transaminase (AST) in A $(112.8 \pm 1.4 \mathrm{U} / \mathrm{L}), \mathrm{B}(110.5 \pm 6.0 \mathrm{U} / \mathrm{L})$, $\mathrm{C}(134.2 \pm 3.5 \mathrm{U} / \mathrm{L})$, Serum alanine transaminase (ALT) in A $(31.7 \pm 2.3 \mathrm{U} / \mathrm{L}), \mathrm{B}(27.3 \pm 2.2$ $\mathrm{U} / \mathrm{L}), \mathrm{C}(40.7 \pm 5.7 \mathrm{U} / \mathrm{L})$ differed significantly $(\mathrm{P}<0.01)$. Creatinine in $\mathrm{A}(0.8 \pm 0.1 \mathrm{mg} / \mathrm{dl})$, $\mathrm{B}(0.7 \pm 0.1 \mathrm{mg} / \mathrm{dl}), \mathrm{C}(0.7 \pm 0.1 \mathrm{mg} / \mathrm{dl})$ did not differ significantly. It is suggested that the probiotics altered blood chemistry in the rats. (Bangl. vet. 2011. Vol. 28, No. 2, 70 - 74)
\end{abstract}

\section{Introduction}

Microorganisms represent an essential component of the mammalian intestinal lumen. While the stomach is sparsely populated by acid-tolerant microbes, postgastric sites support an increasing microbial population density, which can reach up to $10^{11}$ bacteria in the large intestine. Indeed, the body contains approximately ten times as many bacterial cells as somatic cells. Colonization of the intestinal tract by microorganisms begins when a newborn baby encounters maternal and environmental microbes during delivery. As neonatal development continues, the infant's developing intestinal tract is colonised by a succession of bacteria, which normally begin to stabilize at weaning. Probiotics are live microbial food ingredients that may have a beneficial effect on human health (Salminen et al., 1998). Microbial dietary supplements, introduced in sufficient quantities, may benefit humans through their effects in the intestinal tract (Fuller, 1989; Dimer and Gibson, 1998; Lee and Salminen, 1995). Continuous use of antibiotics in animal feed may result in antibiotic residues in animal products and the development of drug-resistant microorganisms in humans. The present study was undertaken to investigate the effect of dietary supplementation of probiotics (BIO-TOP ${ }^{\circledR}$ and curd) on blood biochemical constituents especially serum transaminases, creatinine and lipids. The criteria of microorganisms to beg included in Probiotic that must be normal inhabitant of gut and resistance to acid conditions of stomach, bile, and digestive enzymes normally found in the animal GI tract. 


\section{Materials and Methods}

Twelve one-month-old male rats (Rattus norvegicus) were purchased from the International Centre for Diarrhoeal Disease Research, Bangladesh (ICDDR, B), Dhaka. The rats were randomly assigned to three groups of four, A, B, C.

\section{Experimental diets}

Bio-Top ${ }^{\circledR}$ is a probiotic in dry powder containing Bacillus subtilis, Bacillus licheniformis and zinc oxide, used for supplementation of diets. Curd contains multistrain bacteria. Both were collected from local market. Curd and Bio-Top ${ }^{\circledR}$ were fed as follows:

Group A: Curd $(0.2 \mathrm{gm} / \mathrm{rat})+$ ordinary rat feed; Group B: Bio-Top ${ }^{\circledR}(0.2 \mathrm{gm} / \mathrm{rat})+$ ordinary rat feed; Group C: Ordinary rat feed control.

Ingredients and proximate analysis of rats pellet supplied from ICDDR'B, Dhaka.

\begin{tabular}{lc}
\hline Ingredient & $\mathrm{g} / 100 \mathrm{~g}$ \\
\hline Corn & 12.8 \\
Wheat & 30.0 \\
Rice polish & 6.0 \\
Til oil cake & 6.0 \\
Soya-44 & 3.0 \\
Skimmed meal & 1.0 \\
Wheat bran & 20.0 \\
Fish meal & 10.0 \\
Salt & 0.1 \\
Lysine & 0.9 \\
Vitamin mixture & 0.3 \\
Feed enzyme & 0.1 \\
Soybean oil & 1.0 \\
Sulkil & 0.4 \\
Sarvar tox & 0.3 \\
Lime stone & 0.3 \\
DCP & 0.3 \\
Bengal gram & 8.0 \\
Choline & 0.1 \\
Protein $(\% \mathrm{~N} \times 6.3)$ & 19.7 \\
Fat & 5.8 \\
Fiber & 4.2 \\
Ash & 6.5 \\
\hline
\end{tabular}

These rations were made available for the entire experiment. The diet was prepared daily. Faeces of the rats were cleaned regularly and hygienic and sanitary measures were adopted. 


\section{Collection of blood and preparation of serum}

At the end of experimental period ( 7 weeks) the rats were starved overnight. Sequential anaesthesia was done with 3-4\% chloroform, and blood was collected by incising the abdominal aorta after opening the abdominal cavity. Blood 2-3 ml was collected into sterile glass test tubes. The tubes were placed in slanting position at room temperature for six hours, then overnight at $4^{\circ} \mathrm{C}$. Serum was separated and centrifuged and stored at $-20^{\circ} \mathrm{C}$.

The serum transaminases (ALT, AST), lipid profile (Cholesterol, HDL, LDL, TG) and Creatinine were determined colorimetrically using Humalyzer 2000 (Human type, Germany) in collaboration with AL-Madina Diagnostic Complex, Charpara, Mymensingh.

\section{Statistical analysis}

Data were calculated and analysed using statistical SPSS program for one-way analysis of variance (ANOVA) and Duncan's Multiple Range Test (Duncan, 1955) was done for differences among the treatment means at $1 \%$ level of significance (Kabir et al., 1980).

\section{Results and Discussion}

The blood biochemical values are shown in Table 1.

Table 1. Serum biochemical values (mean \pm SE)

\begin{tabular}{l|r|r|r}
\hline \multirow{2}{*}{ Parameters } & \multicolumn{3}{|c}{ Mean \pm SE } \\
\cline { 2 - 4 } & Group A & Group B & Group C \\
\hline Cholesterol(mg/dl) & $91.6 \pm 3.6^{\mathrm{a}}$ & $92.1 \pm 1.2^{\mathrm{a}}$ & $122.3 \pm 4.9^{\mathrm{b}}$ \\
Triglyceride (mg/dl) & $47.5 \pm 16.4^{\mathrm{a}}$ & $44.0 \pm 5.0^{\mathrm{a}}$ & $146.4 \pm 25.4^{\mathrm{b}}$ \\
HDL(mg/dl) & $79.2 \pm 0.4^{\mathrm{a}}$ & $80.5 \pm 0.9^{\mathrm{a}}$ & $73.7 \pm 1.3^{\mathrm{b}}$ \\
LDL(mg/dl) & $2.8 \pm 0.2^{\mathrm{a}}$ & $2.9 \pm 0.3^{\mathrm{a}}$ & $19.3 \pm 5.9^{\mathrm{b}}$ \\
AST (U/L) & $112.8 \pm 1.4^{\mathrm{a}}$ & $110.5 \pm 6.0^{\mathrm{a}}$ & $134.2 \pm 3.5^{\mathrm{b}}$ \\
ALT (U/L) & $31.7 \pm 2.3^{\mathrm{a}}$ & $27.3 \pm 2.2^{\mathrm{a}}$ & $40.7 \pm 5.7^{\mathrm{b}}$ \\
\hline
\end{tabular}

A significant $(\mathrm{P}<0.01)$ difference in serum cholesterol, TG, HDL and LDL were recorded between the curd and Bio-Top ${ }^{\circledR}$ treated rats. Total cholesterol was higher in group C (122.3 $\pm 4.9 \mathrm{mg} / \mathrm{dl})$ but lower in A $(91.6 \pm 3.6 \mathrm{mg} / \mathrm{dl})$ and Group B $(92.1 \pm 1.2$ $\mathrm{mg} / \mathrm{dl})$. Triglyceride was much higher in group C $(146.4 \pm 25.4 \mathrm{mg} / \mathrm{dl})$ and lower in A $(47.5 \pm 16.4 \mathrm{mg} / \mathrm{dl})$ and $\mathrm{B}(44.0 \pm 5.0 \mathrm{mg} / \mathrm{dl})$.

HDL was significantly higher $(\mathrm{P}<0.01)$ in groups A $(79.2 \pm 0.4 \mathrm{mg} / \mathrm{dl})$ and $\mathrm{B}(80.5$ $\pm 0.9 \mathrm{mg} / \mathrm{dl})$ than in $\mathrm{C}(73.7 \pm 1.3 \mathrm{mg} / \mathrm{dl})$. LDL was significantly lower $(\mathrm{P}<0.01)$ in groups $A$ and $B(2.8 \pm 0.2 \mathrm{mg} / \mathrm{dl}$ and $2.9 \pm 0.3 \mathrm{mg} / \mathrm{dl})$ than in $C(19.3 \pm 5.9 \mathrm{mg} / \mathrm{dl})$. 
The present finding differs from Kwon et al. (2002) who reported insignificant differences in total cholesterol in broilers between the treatment groups.

The present result also differs from Joy (1997); Kwon et al. (2002) who stated that triglyceride, HDL, and LDL and cholesterol were not different between the control and probiotic-treated groups. The results are in agreement with Guyton, (1971) who reported results in humans.

Heart and liver functions have been assessed by the values of AST and ALT. The AST was significantly higher $(\mathrm{P}<0.01)$ in control $(134.2 \pm 3.5 \mathrm{U} / \mathrm{L})$ rats than the curd $(112.8 \pm 1.4 \mathrm{U} / \mathrm{L})$ and Bio-Top ${ }^{\circledR}$ treated $(110.5 \pm 6.0 \mathrm{U} / \mathrm{L})$ rats. Similarly ALT was significantly higher $(\mathrm{P}<0.01)$ in control group $(40.7 \pm 5.7 \mathrm{U} / \mathrm{L})$ than in curd $(31.7 \pm 2.3$ $\mathrm{U} / \mathrm{L})$ and Bio-Top ${ }^{\circledR}$ treated $(27.3 \pm 2.2 \mathrm{U} / \mathrm{L})$ rats.

AST is distributed widely in various organs such as the heart and skeletal muscles as well as liver, whereas ALT exists mainly in the liver. The findings correlate with Islam et al. (2004) who stated that supplementation of probiotics had significant $(\mathrm{P}<0.01)$ influence in AST and ALT values.

Table 2. Serum creatinine

\begin{tabular}{c|c|c|c|c}
\hline \multirow{2}{*}{ Parameters } & \multicolumn{3}{|c|}{ Mean \pm SE } & \multirow{2}{*}{$\begin{array}{c}\text { Level of } \\
\text { significance }\end{array}$} \\
\cline { 2 - 3 } & Group A & Group B & Group C & NS \\
\hline Creatinine $\mathrm{mg} / \mathrm{dl}$ & $0.8 \pm 0.1$ & $0.7 \pm 0.1$ & $0.7 \pm 0.1$ & . \\
\hline
\end{tabular}

Serum creatinine values were insignificantly higher $(\mathrm{P}>0.05)$ in treated groups than control group $(0.7 \pm 0.1 \mathrm{mg} / \mathrm{dl})$.

It is concluded that probiotics affect blood chemicals in rats.

\section{References}

Salminen S, Bouley C, Boutron-Ruault MC, Cummings JH, Franck A, Gibson GR, Isolauri E, Moreau M, Roberfroid M, Rowland I 1998: Functional food science and gastrointestinal physiology and function. British Journal of Nutrition 80 147-171.

Dimer C, Gibson GR 1998: An overview of probiotics, prebiotics and synbiotics in the functional food concept: perspectives and future strategies. International Journal of Dairy Science 8 473-479.

Fuller R 1989: "Probiotics in man and animals." The Journal of Applied Bacteriology 5 365-378.

Lee YK, Salminen S 1995: The coming of age of probiotics. Trends Food Science Technology 6 241-244.

Duncan DB 1955: Duncan Multiple Range and F test. Biometrics 11 1-42. 
Kabir SML, Rahman MM, Rahman MB, Rahman MM. Ahmed SU 2004: The Dynamics of Probiotics on Growth Performance and Immune Response in Broilers International Journal of Poultry Science 3 361-364.

Kwan OS, Kim IH, Hong JW, Han YK, Lee SH, Lee JM 2002: Effects of probiotics supplementation on growth performance, blood composition, and fecal noxious gas of broiler chickens. Korean Journal of Poultry Science 1 1-6.

Guyton RA 1971: Effect of probiotic on lipid profile. International Dairy Journal 370.

Islam MW, Rahman MM, Kabir SML, Kamruzzaman SM, Islam MM 2004: Effect of probiotics supplementation on growth performance and certain haemato-biochemical parameters in broiler chickens. Bangladesh Journal of Veterinary Medicine 2 39-43. 